\title{
A case report of supraventricular tachycardia potentially related to administration of high doses of loperamide (antidiarrheal drug) in a septic shock patient .
}

Heba Shaker ${ }^{1}$ and Samar Fahmy ${ }^{2}$

${ }^{1}$ Alexandria Main University Hospital

${ }^{2}$ Affiliation not available

May 27, 2020

\begin{abstract}
A case of a 43 years old female in intensive care unit admitted with severe and persistent attacks of diarrhea ,she was administered high doses of loperamide and she developed supraventricular tachycardis attacks which disappeared upon dose reduction and then stopping of the drug.
\end{abstract}

Hosted file

case-report after revision.docx available at https://authorea.com/users/326838/ articles/454713-a-case-report-of-supraventricular-tachycardia-potentially-related-toadministration-of-high-doses-of-loperamide-antidiarrheal-drug-in-a-septic-shock-patient

Hosted file

Figure1.docx available at https://authorea.com/users/326838/articles/454713-a-case-reportof-supraventricular-tachycardia-potentially-related-to-administration-of-high-doses-ofloperamide-antidiarrheal-drug-in-a-septic-shock-patient 